\title{
Cross-Resistance between Cisplatin, Antimony Potassium Tartrate, and Arsenite in Human Tumor Cells
}

\author{
Peter Naredi, * Dennis D. Heath, ${ }^{\star}$ Robert E. Enns, ${ }^{\star}$ and Stephen B. Howell* \\ *Department of Surgery, Sahlgrenska University Hospital, S-41345 Göteborg, Sweden; and ${ }^{\ddagger}$ Department of Medicine and the Cancer \\ Center, University of California San Diego, La Jolla, California 92093
}

\begin{abstract}
Cross-resistance between cisplatin (DDP) and metalloid salts in human cells was sought on the basis that mechanisms that mediate metalloid salt cross-resistance in prokaryotes are evolutionarily conserved. Two ovarian and two head and neck carcinoma cell lines selected for DDP resistance were found to be cross-resistant to antimony potassium tartrate, which contains trivalent antimony. The DDP-resistant variant 2008 /A was also cross-resistant to arsenite but not to stibogluconate, which contains pentavalent antimony. A variant selected for resistance to antimony potassium tartrate was cross-resistant to DDP and arsenite. Resistance to antimony potassium tartrate and arsenite was of a similar magnitude (3-7-fold), whereas the level of resistance to DDP was greater (17-fold), irrespective of whether the cells were selected by exposure to DDP or to antimony potassium tartrate. In the resistant sublines, uptake of $\left[{ }^{3} \mathrm{H}\right]$ dichloro(ethylenediamine) platinum(II) was reduced to 41-52\% of control, and a similar deficit was observed in the accumulation of arsenite. We conclude that DDP, antimony potassium tartrate, and arsenite all share a common mechanism of resistance in human cells and that this is due in part to an accumulation defect. (J. Clin. Invest. 1995. 95:1193-1198.) Key words: cisplatin • antimonite $\bullet$ arsenite - resistance $\cdot$ cancer
\end{abstract}

\section{Introduction}

Among several proposed mechanisms for natural and acquired resistance to cisplatin (DDP), ${ }^{1}$ decreased drug accumulation is the most consistent finding both in vivo (1) and in vitro (2) (for reviews see references 3-7). The cause of this impairment in DDP accumulation is unknown, and in fact, the mechanism by which DDP enters or exits from cells remains poorly defined. DDP enters cells relatively slowly compared with the anticancer agents that participate in the multidrug-resistant phenotype, and at least one component of DDP uptake is likely to be mediated

\footnotetext{
Address correspondence to Dr. Stephen B. Howell, Department of Medicine 0812, University of California, San Diego, La Jolla, CA 92093. Phone: 619-543-5530; FAX: 619-543-5258.

Received for publication 12 July 1994 and in revised form 3 November 1994.
}

1. Abbreviations used in this paper: DDP, cisplatin; DEP, cis-dichloro(ethylenediamine) platinum(II).

J. Clin. Invest.

(C) The American Society for Clinical Investigation, Inc.

0021-9738/95/03/1193/06 \$2.00

Volume 95, March 1995, 1193-1198 by a transport mechanism or channel (6-10). DDP efflux is even slower, and it has been difficult to distinguish any major differences in efflux pattern between sensitive and resistant cell lines $(11-13)$.

Several transport-protein complexes that mediate the detoxification of heavy metal salts have been identified in bacteria and yeast and appear to be structurally and functionally well conserved throughout evolution (14-20). During studies directed at identifying metal salts that demonstrated a pattern of cross-resistance similar to that of DDP, we found that a DDPselected subline of the human ovarian carcinoma 2008 line was cross-resistant to antimony potassium tartrate, and an antimony potassium tartrate-selected variant was cross-resistant to DDP (Naredi, P., and S. B. Howell, unpublished data). In both resistant variants, there was an impairment of the uptake of the DDP analog $\left[{ }^{3} \mathrm{H}\right]$-cis-dichloro(ethylenediamine) platinum(II) $\left(\left[{ }^{3} \mathrm{H}\right] \mathrm{DEP}\right)$. Antimony potassium tartrate contains antimony in a trivalent form, and one mechanism of resistance to trivalent antimonials in bacteria is mediated by genes that make up the ars operon (21). In Escherichia coli and Staphylococcus aureus, this operon codes for a specific efflux-transport system that can export oxyanions of antimony but is best known for its ability to confer resistance to arsenic oxyanions (21). In the protozoa Leishmania, the lmpgp gene has also been reported to confer resistance to both antimony potassium tartrate and arsenite (19).

The aim of this study was to determine the extent to which human ovarian carcinoma cells selected for resistance to DDP are cross-resistant to oxyanions that share a common mechanism of resistance in bacteria. The results indicated that cells selected for resistance to DDP were cross-resistant not only to antimony potassium tartrate, but also to arsenite (see Fig. 1 for structures) and that cells selected for resistance to antimony potassium tartrate showed the same cross-resistant phenotype. In addition, both DDP- and antimony potassium tartrate-selected cells demonstrated impaired accumulation of radiolabeled arsenite that was of the same magnitude as the impairment in the uptake of the DDP analog $\left[{ }^{3} \mathrm{H}\right] \mathrm{DEP}$. The results provide evidence for a common mechanism of resistance to DDP and oxyanions of antimony and arsenic based on a defect in a shared accumulation mechanism system.

\section{Methods}

Materials. DDP $\left(\mathrm{Pt}(\mathrm{Cl})_{2}\left(\mathrm{NH}_{3}\right)_{2}\right)$ was obtained from the Bristol-Myers Co. (Syracuse, NY). Sodium arsenite $\left(\mathrm{Na}_{3} \mathrm{AsO}_{3}\right)$ was purchased from Sigma Chemical Co. (St. Louis, MO). Antimony potassium tartrate (bis [ $\mu$-[2,3-dihydroxybutanedioato(4-)-01, 02:03, 04]]-diantimonate dipotassium trihydrate $)\left(\mathrm{C}_{8} \mathrm{H}_{4} \mathrm{~K}_{2} \mathrm{O}_{12} \mathrm{Sb}_{2} \cdot 3 \mathrm{H}_{2} \mathrm{O}\right)$ was obtained from Aldrich Chemical Co. (Milwaukee, WI). Stibogluconate $\left(\mathrm{C}_{12} \mathrm{H}_{17} \mathrm{O}_{17} \mathrm{Sb}_{2}\right.$. $\mathrm{Na}_{3}$ ) was obtained from Burroughs Wellcome (UK). [ $\left.{ }^{3} \mathrm{H}\right] \mathrm{DEP}$ $\left(\mathrm{PtCl}_{2} \mathrm{~N}_{2} \mathrm{C}_{2} \mathrm{H}_{8}\right)$ was synthesized as previously described (22). Radioac- 


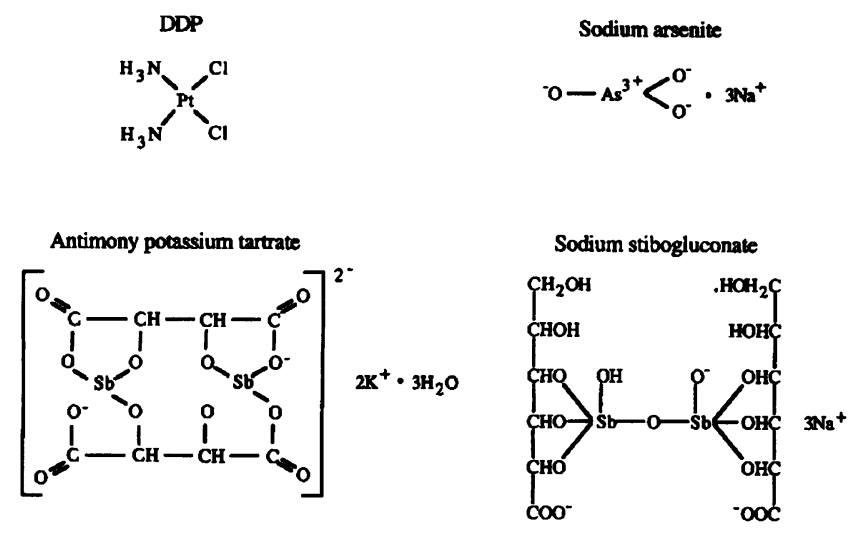

Figure 1. Structures of DDP, sodium arsenite, and antimony potassium tartrate, and stibogluconate.

tive arsenate $\left({ }^{73} \mathrm{AsO}_{4}\right)$ was purchased from Los Alamos National Laboratory (Los Alamos, NM).

Tumor cell lines. The human cell line 2008 was established from a patient with a serous cystadenocarcinoma of the ovary (23). A resistant subline, designated 2008/A, was produced by four selections with 0.5 $\mu \mathrm{M}$ DDP over a 1 -mo period. $2008 / \mathrm{H}$ was obtained by chronic exposure of 2008 cells to antimony potassium tartrate, during which the drug concentration was increased stepwise to $140 \mu \mathrm{M}$ over $8 \mathrm{mo}$. A2780 is a human ovarian cancer cell line, and A2780/CP is a DDP-selected variant (24). UMSCC5 and UMSCC10b were derived from human squamous cell carcinomas in the head and neck region $(25,26)$. The DDP-resistant UMSCC5/DDP and UMSCC10b/DDP lines were selected by chronic exposure to DDP with incremental increases in DDP concentration to 0.6 and $0.8 \mu \mathrm{M}$, respectively, over $5 \mathrm{mo}$ (27). The present studies were performed after cells had been passaged in drugfree media a minimum of three times. The cells were grown on tissue culture dishes in a humidified incubator at $37^{\circ} \mathrm{C}$ in a $5 \% \mathrm{CO}_{2}$ atmosphere. They were maintained in complete medium consisting of RPMI 1640 (Irvine Scientific, Santa Ana, CA) supplemented with 5\% (10\% for UMSCC cells) heat-inactivated FCS and $2 \mathrm{mM}$ glutamine. Cultures were routinely tested for mycoplasma using a kit from Gen Probe Inc. (San Diego, CA) and were found to be negative.

Clonogenic assays. Cells in exponential growth were trypsinized from monolayer culture and adjusted to a concentration of 60 cells per $\mathrm{ml}$. A volume of $5 \mathrm{ml}$ was plated onto $60-\mathrm{mm}$ polystyrene tissue culture dishes (Corning Glass Works, Corning, NY). Stock solutions of drugs to be tested were added to triplicate plates at each drug concentration. Plates were incubated at $37^{\circ} \mathrm{C}$ in a $5 \% \mathrm{CO}_{2}$ humidified atmosphere, and after $10 \mathrm{~d}$, the plates were fixed with methanol and stained with Giemsa. Colonies of over 50 cells were counted macroscopically. Each experiment was repeated a minimum of three times using triplicate cultures.

$\left[{ }^{3} \mathrm{H}\right] D E P$ accumulation. Uptake was measured with subconfluent cells by addition of $5 \mu \mathrm{M}\left[{ }^{3} \mathrm{H}\right] \mathrm{DEP}(5 \mu \mathrm{Ci} / \mathrm{ml})$ to triplicate cultures for the indicated period of time. Immediately after completion of $\left[{ }^{3} \mathrm{H}\right] \mathrm{DEP}$ exposure, the cells were washed six times with a total of $20 \mathrm{ml}$ of $4^{\circ} \mathrm{C}$ PBS and lysed in $2 \mathrm{ml}$ of $1 \mathrm{~N} \mathrm{NaOH}$ overnight. An aliquot was removed for protein determination by the method of Bradford (28). Radioactivity was determined by liquid scintillation counting. Each experiment was performed a minimum of three times with triplicate cultures.

Synthesis of ${ }^{73} \mathrm{AsO}_{3}$. Radioactive arsenate was chemically reduced to arsenite as described previously (29). $40 \mu \mathrm{l}$ of ${ }^{73} \mathrm{AsO}_{4}(0.5 \mu \mathrm{Ci} / \mu \mathrm{l})$ was mixed with $40 \mu \mathrm{l}$ of a reducing solution consisting of $1 \mathrm{mM}$ $\mathrm{Na}_{3} \mathrm{AsO}_{4}, 66 \mathrm{mM} \mathrm{Na}_{2} \mathrm{~S}_{2} \mathrm{O}_{5}, 27 \mathrm{mM} \mathrm{Na}_{2} \mathrm{~S}_{2} \mathrm{O}_{3}$, and $82 \mathrm{mM} \mathrm{H}_{2} \mathrm{SO}_{4}$. After 40 min at room temperature, $>99.5 \%$ of ${ }^{73} \mathrm{AsO}_{4}$ was reduced to ${ }^{73} \mathrm{AsO}_{3}$, as verified by HPLC. Freshly reduced ${ }^{73} \mathrm{AsO}_{3}$ was made each day.

${ }^{73} \mathrm{AsO}_{3}$ accumulation. Uptake was measured using subconfluent cells growing in $60-\mathrm{mm}$ dishes by addition of $3 \mu \mathrm{M}{ }^{73} \mathrm{AsO}_{3}(0.25 \mu \mathrm{Ci} / \mathrm{ml})$ to duplicate cultures for the indicated period of time. Immediately after
Table I. Cytotoxicity of DDP and Antimony Potassium Tartrate against Human Ovarian and Squamous Head and Neck Carcinoma Cell Lines

\begin{tabular}{|c|c|c|c|c|}
\hline \multirow[b]{2}{*}{ Cell line } & \multicolumn{2}{|c|}{ DDP } & \multicolumn{2}{|c|}{$\begin{array}{l}\text { Antimony potassium } \\
\text { tartrate }\end{array}$} \\
\hline & $\mathrm{IC}_{50}(\mu M)$ & $\begin{array}{l}\text { Fold } \\
\text { resistant }\end{array}$ & $\mathrm{IC}_{50}(\mu M)$ & $\begin{array}{l}\text { Fold } \\
\text { resistant }\end{array}$ \\
\hline 2008 & $0.13 \pm 0.01 *$ & & $3.4 \pm 0.2$ & \\
\hline 2008/A & $2.6 \pm 0.8$ & $17 \pm 4^{\ddagger}$ & $17 \pm 1$ & $4.9 \pm 0.4^{\ddagger}$ \\
\hline A2780 & $0.25 \pm 0.09$ & & $0.53 \pm 0.24$ & \\
\hline $\mathrm{A} 2780^{\mathrm{CP}}$ & $2.6 \pm 0.4$ & $11 \pm 3^{\ddagger}$ & $4.8 \pm 1.3$ & $7.2 \pm 0.3^{\ddagger}$ \\
\hline UMSCC 10b & $0.27 \pm 0.01$ & & $4.0 \pm 1.1$ & \\
\hline UMSCC10b/DDP & $0.53 \pm 0.07$ & $2.0 \pm 0.2^{\ddagger}$ & $8.4 \pm 1.4$ & $2.1 \pm 0.2^{\ddagger}$ \\
\hline UMSCC5 & $0.27 \pm 0.02$ & & $4.0 \pm 1.1$ & \\
\hline UMSCC5/DDP & $0.62 \pm 0.06$ & $2.3 \pm 0.3^{\ddagger}$ & $8.7 \pm 0.9$ & $2.3 \pm 0.6^{\ddagger}$ \\
\hline
\end{tabular}

* Data are mean \pm SD of three determinations performed with triplicate cultures. ${ }^{\ddagger}$ Significantly different $(P<0.05)$ compared with the parent cell line, as determined by paired Student's $t$ test.

completion of ${ }^{73} \mathrm{AsO}_{3}$ exposure, the cells were washed and lysed as for the $\left[{ }^{3} \mathrm{H}\right]$ DEP accumulation experiments. Protein determination and radioactivity measurements were also similar. Each experiment was repeated a minimum of three times.

$\left[{ }^{3} \mathrm{H}\right] \mathrm{DEP}$ and ${ }^{73} \mathrm{AsO}_{3}$ efflux. Subconfluent cells were prepared on dishes as for the accumulation experiments and loaded with drug by incubation with $5 \mu \mathrm{M}\left[{ }^{3} \mathrm{H}\right] \mathrm{DEP}(5 \mu \mathrm{Ci} / \mathrm{ml})$ or $3 \mu \mathrm{M}^{73} \mathrm{AsO}_{3}(0.25 \mu \mathrm{Ci} /$ $\mathrm{ml}$ ) for $120 \mathrm{~min}$. At the end of the loading period, they were washed six times with a total of $20 \mathrm{ml}$ of $37^{\circ} \mathrm{C}$ PBS. Drug-free medium was then added, and the cells were incubated at $37^{\circ} \mathrm{C}$ for the indicated efflux time. Efflux was terminated by washing six times with a total of $20 \mathrm{ml}$ of PBS at $4^{\circ} \mathrm{C}$. The monolayers were assayed for protein determination and radioactivity for the uptake experiments. Each experiment was repeated three times with duplicate cultures.

Statistics. $\mathrm{IC}_{50}$ was defined as the concentration of drug that reduced the number of colonies to $50 \%$ of that in the untreated control cultures. Statistical significance of data was determined by paired Student's $t$ test. $P<0.05$ was considered to be statistically significant. All values reported are mean $\pm S D$.

\section{Results}

Two pairs of DPP-sensitive and -resistant human ovarian carcinoma cell lines and two pairs of human head and neck carcinoma cells lines were tested for cross-resistance to antimony potassium tartrate. The $\mathrm{IC}_{50}$ values for the parental 2008 and A2780 human ovarian carcinoma cell lines were $0.13 \pm 0.01$ and $0.25 \pm 0.09 \mu \mathrm{M}$, respectively, for DDP and $3.4 \pm 0.2$ and $0.53 \pm 0.24 \mu \mathrm{M}$, respectively, for antimony potassium tartrate (Table I). The 17-fold DDP-resistant, DDP-selected subline 2008/A was 4.9-fold cross-resistant to antimony potassium tartrate $(P<0.05)$, and the 11 -fold DDP-resistant, DDP-selected subline A2780/CP was 7.2-fold cross-resistant to antimony potassium tartrate $(P<0.05)$. Thus, both DDP-resistant variants of the ovarian carcinoma cell lines demonstrated substantial cross-resistance to antimonite. The same observation was made for the two head and neck carcinoma cell lines. The parental human squamous head and neck carcinoma cell lines UMSCC10b and UMSCC5 had similar $\mathrm{IC}_{50}$ values for DDP $(0.27 \pm 0.01$ and $0.27 \pm 0.02 \mu \mathrm{M}$, respectively) and for antimony potassium tartrate $(4.0 \pm 1.1 \mu \mathrm{M}$ for both) (Table I). The DDP- 

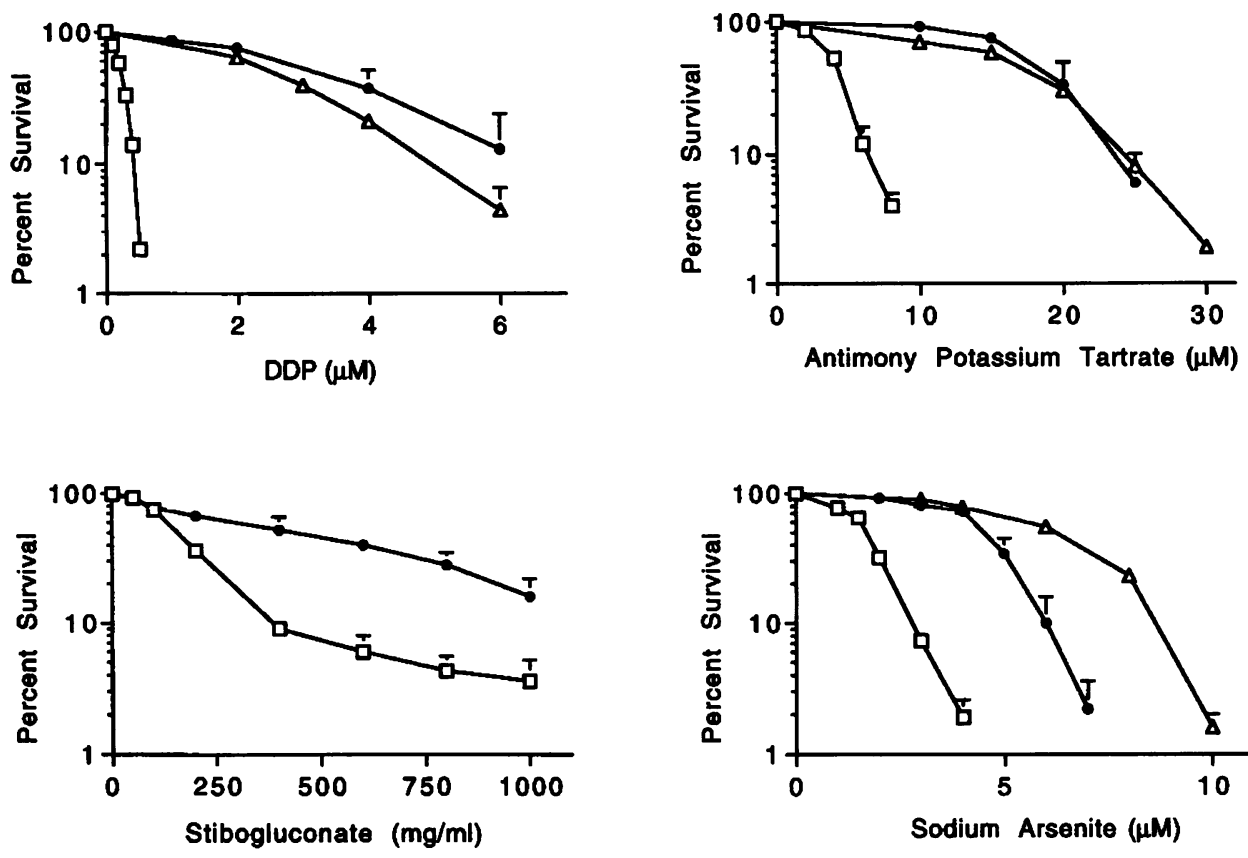

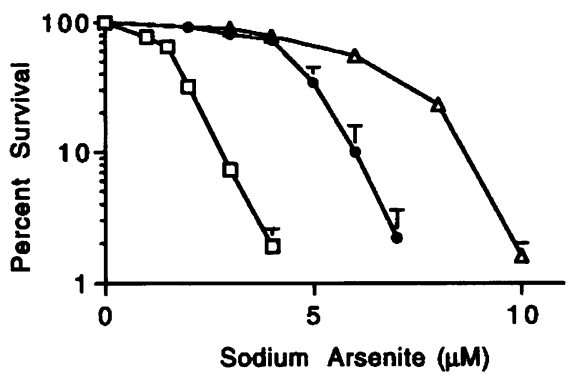

Figure 2. Dose-response curves for DDP (top left), antimony potassium tartrate (top right), stibogluconate (bottom left), and sodium arsenite (bottom right), as determined by clonogenic assay. (Open squares) 2008 cells; (closed circles) 2008/A cells; (open triangles) 2008/H cells. Data points represent the mean $\pm \mathrm{SD}$ of three experiments performed with triplicate cultures. selected variant UMSCC10b/DDP was 2.0-fold resistant to DDP and 2.1-fold cross-resistant to antimony potassium tartrate $(P<0.05)$. The DDP-selected UMSCC5/DDP cells were 2.3fold resistant to both DDP and antimony potassium tartrate ( $P$ $<0.05)$. Thus, all four DDP-resistant variants demonstrated cross-resistance to antimony potassium tartrate, and there was a good correlation $(r=0.75)$ between the magnitude of the DDP resistance and the magnitude of the cross-resistance to antimony potassium tartrate.

Antimony potassium tartrate contains antimony in its trivalent form. The 17-fold DDP-resistant 2008/A subline was tested for cross-resistance to stibogluconate, which contains antimony in its pentavalent form, and to arsenite, which contains arsenic in its trivalent form. Fig. 2 shows that 2008/A cells were crossresistant to arsenite but not stibogluconate. The $\mathrm{IC}_{50}$ for stibogluconate tested against the parental 2008 cells was $30 \pm 9 \mu \mathrm{g} /$ $\mathrm{ml}$, whereas for the $2008 \mathrm{~A}$ cells, it was $26 \pm 13 \mu \mathrm{g} / \mathrm{ml}$. The $\mathrm{IC}_{50}$ for arsenite against the parental 2008 cells was $1.5 \pm 0.1 \mu \mathrm{M}$, and for the 2008/A subline, it was 4.5 $\pm 0.1 \mu \mathrm{M}$ (3.0-fold resistant $)(P<0.05)$. Thus, the mechanism protecting $2008 / \mathrm{A}$ cells against DDP did not offer any protection against a pentavalent antimonial, but did offer a substantial degree of protection against a trivalent oxyanion of arsenic.

If DDP, antimony potassium tartrate, and arsenite share a common mechanism of resistance, then one might expect that cells selected for resistance to antimony potassium tartrate would also be resistant to DDP and arsenite, but not to stibogluconate. Fig. 2 shows the survival curves for the antimony potassium tartrate-selected $2008 / \mathrm{H}$ cells for DDP, antimony potassium tartrate, sodium arsenite, and stibogluconate. The $\mathrm{IC}_{50}$ for antimony potassium tartrate against $2008 / \mathrm{H}$ cells was $14 \pm 1$ $\mu \mathrm{M}$, indicating that they were 6.6-fold resistant compared with the parental 2008 cells. They were also 16 1 -fold cross-resistant to DDP $(P<0.05)$ and $4.3 \pm 0.5$-fold cross-resistant to sodium arsenite $(P<0.05)$, but were not cross-resistant to stibogluconate. Thus, each of the predictions was substantiated, arguing strongly for a common underlying mechanism of resistance.
Previous studies with DDP-selected variants of 2008 cells had demonstrated impaired uptake of both DDP $(2,9,11)$ and an analog of DDP, DEP, which can be labeled to high specific activity with ${ }^{3} \mathrm{H}$ (30). Fig. 3 (top panel) shows the time course of $\left[{ }^{3} \mathrm{H}\right.$ ]DEP accumulation over $2 \mathrm{~h}$ in the parental 2008 cells and in DDP- and antimony potassium tartrate-selected variants. The rate of [ ${ }^{3} \mathrm{H}$ ] DEP accumulation in 2008 cells was $0.56 \pm 0.21$ $\mathrm{pmol} / \mathrm{mg}$ protein per min. In the 2008/A subline, the uptake rate was reduced to $0.29 \pm 0.04 \mathrm{pmol} / \mathrm{mg}$ per $\min$ ( $52 \%$ of control; $P$ $<0.05)$. Likewise, in $2008 / \mathrm{H}$ cells, the uptake rate was reduced to $0.23 \pm 0.05 \mathrm{pmol} / \mathrm{mg}$ per $\mathrm{min}(41 \%$ of control; $P<0.05$ ). Total accumulation of $\left[{ }^{3} \mathrm{H}\right] \mathrm{DEP}$ at $2 \mathrm{~h}$ in 2008 cells was $88 \pm 20$ $\mathrm{pmol} / \mathrm{mg}$ protein. It was $67 \%$ of this control value in the 2008 / A variant $(59 \pm 4 \mathrm{pmol} / \mathrm{mg}$ protein) and $52 \%$ of control in the $2008 / \mathrm{H}$ subline $(46 \pm 8 \mathrm{pmol} / \mathrm{mg}$ protein $)(P<0.05$ for both resistant cell types ).

If impaired uptake is a central component of the mechanism underlying the shared DDP/antimonite/arsenite-resistant phenotype, then one might expect that both the DDP- and the antimony potassium tartrate-resistant sublines would also demonstrate an impairment in the uptake of antimony potassium tartrate and arsenite. A radiolabeled form of antimony potassium tartrate was not available for such studies, but radioactive ${ }^{73} \mathrm{AsO}_{3}$ was successfully obtained. Fig. 3 (bottom panel) shows the time course for the uptake of ${ }^{73} \mathrm{AsO}_{3}$ during a 2-h exposure. The rates of ${ }^{73} \mathrm{AsO}_{3}$ accumulation were statistically significantly lower in the resistant sublines $(2008$ cells, $2.7 \pm 0.4 \mathrm{pmol} / \mathrm{mg}$ per min; 2008/A cells, $1.3 \pm 0.1 \mathrm{pmol} / \mathrm{mg}$ per min; and 2008/ $\mathrm{H}$ cells, $1.2 \pm 0.1 \mathrm{pmol} / \mathrm{mg}$ per $\mathrm{min})$. The accumulation of ${ }^{73} \mathrm{AsO}_{3}$ at $2 \mathrm{~h}$ was $332 \pm 35 \mathrm{pmol} / \mathrm{mg}$ protein in the parental 2008 cells. In the $2008 / \mathrm{A}$ cells, is was $52 \%$ lower $(160 \pm 14$ $\mathrm{pmol} / \mathrm{mg}$ protein ), and in the $2008 / \mathrm{H}$ cells, accumulation was $56 \%$ lower ( $146 \pm 10 \mathrm{pmol} / \mathrm{mg}$ protein ) when measured at $2 \mathrm{~h}$. To exclude the possibility that measurement of ${ }^{73} \mathrm{AsO}_{3}$ uptake was confounded by the presence of contaminating ${ }^{73} \mathrm{AsO}_{4}$, the

${ }^{73} \mathrm{AsO}_{3}$ was analyzed by HPLC and found to contain $<0.5 \%$

${ }^{73} \mathrm{AsO}_{4}$. In addition, the uptake of ${ }^{73} \mathrm{AsO}_{4}$ was found to be only $3.3-5.4 \%$ of that of ${ }^{73} \mathrm{AsO}_{3}$, making it very unlikely that the 

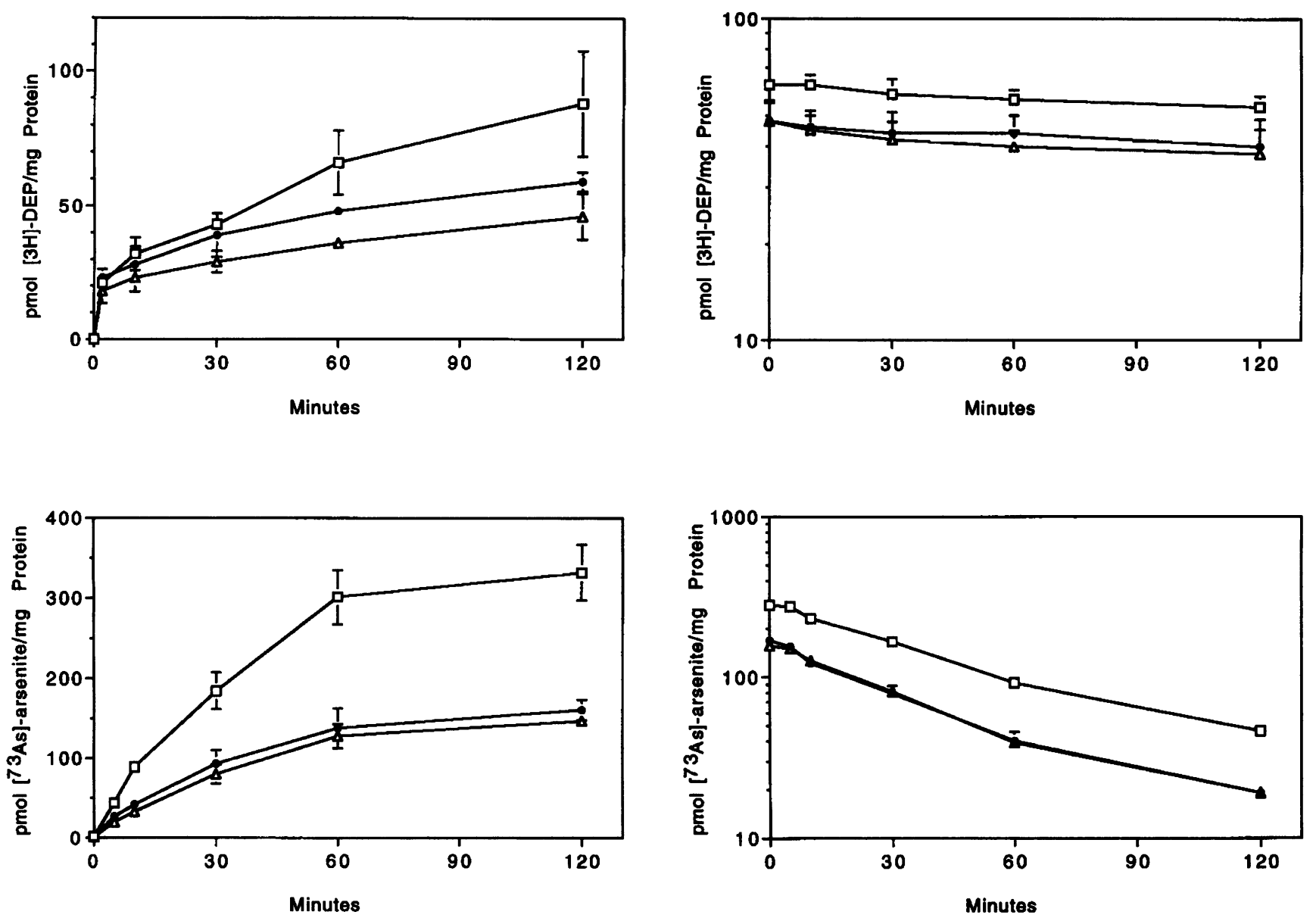

Figure 3. Time course of $\left[{ }^{3} \mathrm{H}\right] \mathrm{DEP}$ (top panel) and ${ }^{73} \mathrm{AsO}_{3}$ (bottom panel) uptake during exposure to $5 \mu \mathrm{M}\left[{ }^{3} \mathrm{H}\right] \mathrm{DEP}(5 \mu \mathrm{Ci} / \mathrm{ml})$ or $3 \mu \mathrm{M}$ ${ }^{73} \mathrm{AsO}_{3}(0.25 \mu \mathrm{Ci} / \mathrm{ml}$ ) for $2 \mathrm{~h}$. (Open squares) 2008 cells; (closed circles) 2008/A cells; (open triangles) 2008/H cells. Data points represent the mean \pm SD of three experiments performed with triplicate $\left(\left[{ }^{3} \mathrm{H}\right]\right.$ DEP) or duplicate $\left({ }^{73} \mathrm{AsO}_{3}\right)$ cultures.

differences in uptake of ${ }^{73} \mathrm{AsO}_{3}$ among the three cells could be attributed to differences in ${ }^{73} \mathrm{AsO}_{4}$ uptake. We conclude that both the DDP- and the antimonite-selected sublines had a deficit in the uptake of both $\left[{ }^{3} \mathrm{H}\right] D E P$ and ${ }^{73} \mathrm{AsO}_{3}$ and that the magnitude of this deficit was quite similar for both radiolabeled compounds.

To determine whether the impaired accumulation of $\left[{ }^{3} \mathrm{H}\right]-$ DEP and ${ }^{73} \mathrm{AsO}_{3}$ in the resistant sublines was due solely to a decrease in influx, the rate of efflux was compared in each of the lines. Fig. 4 (top panel) shows that the efflux of $\left[{ }^{3} \mathrm{H}\right] \mathrm{DEP}$ from the parental 2008 cells was very slow, with $85 \%$ of the accumulated drug remaining in the cells after $2 \mathrm{~h}$ of efflux into drug-free medium. There was no difference in efflux in the $2008 / \mathrm{A}$ and $2008 / \mathrm{H}$ variants, which retained 83 and $79 \%$, respectively, of the $\left[{ }^{3} \mathrm{H}\right]$ DEP present at the start of the efflux period. The efflux rate of ${ }^{73} \mathrm{AsO}_{3}$ was 4-fold greater than that of $\left[{ }^{3} \mathrm{H}\right]$ DEP $(0.72 \pm 0.05 \% / \mathrm{min}$ versus $0.16 \pm 0.16 \% / \mathrm{min} ; P$ $<0.05$ ), but there was no difference in the rate of efflux between the 2008, 2008/A, and 2008/H cells. Only $16 \%$ of the ${ }^{73} \mathrm{AsO}_{3}$ remained in the 2008 cells after $2 \mathrm{~h}$; in the case of the 2008/A and 2008/H cells, it was 14 and 13\%, respectively. Thus, the mechanism underlying the DDP/antimony/arsenite-

Figure 4. Time course of efflux of $\left[{ }^{3} \mathrm{H}\right] \mathrm{DEP}$ (top panel) and ${ }^{73} \mathrm{AsO}_{3}$ (bottom panel) after loading cells by exposure to $5 \mu \mathrm{M}\left[{ }^{3} \mathrm{H}\right] \mathrm{DEP}(5$ $\mu \mathrm{Ci} / \mathrm{ml}$ ) or $3 \mu \mathrm{M}{ }^{73} \mathrm{AsO}_{3}(0.25 \mu \mathrm{Ci} / \mathrm{ml})$ for $2 \mathrm{~h}$. (Open squares) 2008 cells; (closed circles) 2008/A cells; (open triangles) 2008/H cells. Data points represent the mean \pm SD of three experiments performed with triplicate $\left(\left[{ }^{3} \mathrm{H}\right] \mathrm{DEP}\right)$ or duplicate $\left({ }^{73} \mathrm{AsO}_{3}\right)$ cultures.

resistant phenotype impacted exclusively on accumulation and had no discernable effect on efflux.

\section{Discussion}

The results reported here disclose a novel aspect of the DDPresistant phenotype by demonstrating that the phenotype includes cross-resistance to antimony potassium tartrate and arsenite. The DDP-resistant phenotype has been characterized in several human carcinomas, both in vitro and in vivo, and in some circumstances, it has been shown to include cross-resistance to gamma radiation, UV light, other heavy metals and platinum-containing drugs, methotrexate, and alkylating agents (for reviews see references 3-5). However, DDP resistance is not accompanied by resistance to drugs that participate in the multidrug-resistant phenotype mediated by the $\mathrm{mdrl}$ gene product $(31,32)$; nor has it previously been reported to be accompanied by resistance to antimony- or arsenic-containing agents.

In this study, four different human DDP-resistant tumor cell lines representing two different histologic types of cancer were found to be cross-resistant to antimony potassium tartrate. There was a correlation between the level of DDP resistance and the 
degree of cross-resistance to antimony potassium tartrate ( $r$ $=0.75)$. In addition, primary resistance to DDP and crossresistance to antimony potassium tartrate were accompanied by cross-resistance to arsenite, and the same pattern of crossresistance to DDP and arsenite was observed in 2008 cells selected for primary resistance to antimony potassium tartrate. In 2008 cells demonstrating the DDP/antimonite/arsenite-resistant phenotype, the level of resistance to antimony potassium tartrate and arsenite was of a similar magnitude (3-7-fold), whereas the level of resistance to DDP was somewhat greater (17-fold), irrespective of whether the cells were selected by exposure to either DDP or antimony potassium tartrate. Interestingly, 2008 cells expressing the DDP/antimonite/arsenite-resistant phenotype, whether selected primarily with DDP or with antimony potassium tartrate, were not cross-resistant to antimony in its pentavalent state, as found in stibogluconate. We now refer to the phenotype of cells cross-resistant to DDP, arsenite, and antimony potassium tartrate as the RASP phenotype (esistance to $\underline{\mathrm{A}} \mathrm{s} / \underline{\mathrm{S}} \mathrm{b} / \underline{\mathrm{P}} \mathrm{t}$ )

Impairment in the uptake of DDP and $\left[{ }^{3} \mathrm{H}\right] \mathrm{DEP}$ has been observed in many types of cells selected for resistance to DDP $(9,13,33)$, as well as the $2008 / \mathrm{A}$ subline. The antimony potassium tartrate-selected $2008 / \mathrm{H}$ subline not only had a crossresistance profile similar to that of the DDP-selected 2008/A subline, but also had the same degree of impairment in $\left[{ }^{3} \mathrm{H}\right]$ DEP uptake. In addition, both the DDP-resistant and antimony potassium tartrate-resistant variants demonstrated an impairment in the uptake of radiolabeled arsenite, and as for $\left[{ }^{3} \mathrm{H}\right] \mathrm{DEP}$, the impairment in arsenite accumulation was of the same magnitude in both resistant variants. In contrast, there was no evidence of an alteration in efflux. Whereas the efflux of arsenite was four times faster during the 2-h observation period than the efflux of $\left[{ }^{3} \mathrm{H}\right] \mathrm{DEP}$, no difference was observed for either agent in the efflux rate between the sensitive and resistant cells. It is clear that resistance to DDP is multifactorial (5) and not due solely to decreased accumulation. It appears that this is also the case for arsenite and that for this drug too there is not tight linkage between the magnitude of the decrease in uptake and the degree of resistance.

The mechanism by which DDP enters or exits from cells remains poorly defined (3). DDP uptake is not saturable within the limits of its solubility in tissue culture medium, which argues that either DDP enters cells by passive diffusion, or saturation occurs only at concentrations above its maximum solubility (11, 33). Thus far, no membrane changes of a magnitude sufficient to account for the observed decrease in uptake due to a change in passive diffusion of DDP have been found in DDP-resistant 2008 sublines (34). On the other hand, there is increasing evidence that DDP accumulation is mediated in part by an active transporter or channel that is dependent on a functional $\left(\mathrm{Na}^{+} /\right.$ $\mathrm{K}^{+}$)-ATPase, membrane potential, extracellular $\mathrm{pH}$, and extracellular osmolality (for review see reference 3 ). In addition, DDP accumulation can be inhibited by $\sim 50 \%$ by a variety of agents (8). Current evidence supports a model of DDP accumulation that involves contributions from both passive diffusion and a transporter or gated channel (3). Although antimony potassium tartrate and stibogluconate have structures quite different from those of cisplatin and sodium arsenite, the structure of the former two drugs in an aqueous environment is not known, and it is unclear what form of the drug is actually taken up into the cell. At physiologic $\mathrm{pH}$, DDP probably crosses the membrane as a neutral drug and arsenite is present largely as arsenous acid $\left(\mathrm{As}(\mathrm{OH})_{3}\right)$, which is also neutral. There is a strong suspicion that antimony potassium tartrate and stibogluconate come apart in an aqueous environment and that they cross the membrane as oxyanions, but no information is currently available as to the actual charge or molecular weight of the form that gets into the cell.

Impairment in arsenite accumulation, as well as that of antimony potassium tartrate, is also observed in drug-resistant strains of bacteria and the promastigote Leishmania; however, in these organisms, the impaired accumulation is due to enhanced efflux rather than decreased influx. In bacteria there is a welldefined plasmid-encoded efflux system belonging to the ATPbinding cassette family that exports arsenite and metabolites of antimony potassium tartrate. The efflux transporter consists of the membrane-spanning subunit, ArsB, a specific protein for the reduction of pentavalent anions to the trivalent state, $\mathrm{ArsC}$, and in gram-negative bacteria, also a third protein, ArsA, with ATPase activity $(21,35)$. No example of resistance due to decreased influx of arsenite or antimony-containing anions has been reported in bacteria. In fact, whereas pentavalent arsenic (arsenate) is known to be taken up by the phosphate transport system in both bacteria and human cells $(21,36)$, nothing is known about the uptake of the trivalent forms of arsenic and antimony, such as arsenite and antimony potassium tartrate.

In the protozoa Leishmania, the Impgp gene has been reported to confer resistance to the trivalent antimony compound antimony potassium tartrate, but not to stibogluconate, which contains antimony in the pentavalent state (19). In contrast, resistance of Leishmania to pentavalent antimonials has been associated with the expression of a $P$-glycoprotein-like molecule coded for by the ltpgpA gene (37), and such resistance can be reversed by verapamil (38). Stibogluconate-resistant Leishmania were reported to accumulate two to five times less $\left[{ }^{125} \mathrm{Sb}\right]$ stibogluconate than sensitive clones, and the $P$-glycoprotein-specific antibody C219 detected a protein in Leishmania whose molecular weight was the same as that of $P$-glycoprotein in the multidrug-resistant human KB carcinoma sublines (39). Thus, the phenotype generated by amplification of the lmpgp gene appears to be closer to the RASP phenotype in human cells than that produced by the ltpgpA gene.

The discovery that the DDP-resistant phenotype also includes resistance to antimony potassium tartrate and arsenite begs the question of whether this form of resistance extends to other metalloid salts, such as selenite or tellurite, in particular because biochemical mechanisms for the detoxification of several of these salts are well described and may be relevant to the detoxification of DDP in some tissues. The fact that the phenotype includes impaired uptake of arsenite is also of interest because it provides an additional putative substrate for the DDP uptake pathway, available in an easily usable radiolabeled form, with which to study the specificity of the accumulation mechanism.

\section{Acknowledgments}

This work was supported by grants from the National Institutes of Health (CA-55725), the American Cancer Society (DHP26F), the Swedish Medical Research Council, the Assar Gabrielsson's Foundation for Cancer Research, the Swedish Institute, and the King Gustav V Jubilee Clinic Cancer Research Foundation in G̈oteborg. This work was conducted in part by the Clayton Foundation for Research-California Division. Dr. Howell is a Clayton Foundation Investigator. 


\section{References}

1. Loehrer, P. J., and L. H. Einhorn. 1984. Cisplatin. Ann. Intern. Med. 100:704-713.

2. Andrews, P. A., J. A. Jones, N. M. Varki, and S. B. Howell. 1990. Rapid emergence of acquired cis-diamminedichloroplatinum(II) resistance in an in vivo model of human ovarian carcinoma. Cancer Commun. 2:93-100.

3. Gately, D. P., and S. B. Howell. 1993. Cellular accumulation of the anticancer agent cisplatin: a review. Br. J. Cancer. 67:1171-1176.

4. Timmer-Bosscha, H., N. H. Mulder, and E. G. E. DeVries. 1992. Modulation of cis-diamminedichloroplatinum( Ii ) resistance: a review. Br. J. Cancer. 66:227238.

5. Andrews, P. A., and S. B. Howell. 1990. Cellular pharmacology of cisplatin: perspectives on mechanism of acquired resistance. Cancer Cells. 2:35-42.

6. Dornish, J. M., E. O. Pettersen, and R. Oftebro. 1989. Modifying effect of cinnamaldehyde and cinnamaldehyde derivates on cell inactivation and cellular uptake of cis-diamminedichloroplatinum( II) in human NHIK 3025 cells. Cancer Res. 49:3917-3921.

7. Andrews, P. A., and K. D. Albright. 1991. Role of membrane ion transport in cisplatin accumulation. In Platinum and Other Metal Coordination Compounds in Cancer Chemotherapy. S. B. Howell, editor. Plenum Publishing Corp., New York. $151-159$.

8. Andrews, P. A., S. C. Mann, H. H. Huynh, and K. D. Albright. 1991. Role of $\mathrm{Na}^{+}, \mathrm{K}^{+}$-adenosine triphosphatase in the accumulation of cis-diamminedichloroplatinum(II) in human ovarian carcinoma cells. Cancer Res. 51:3677-3681.

9. Andrews, P. A., S. Velury, S. C. Mann, and S. B. Howell. 1988. cisDiamminedichloroplatinum(II) accumulation in sensitive and resistant human ovarian carcinoma cells. Cancer Res. 48:68-73.

10. Mann, S. C., P. A. Andrews, and S. B. Howell. 1991. Modulation of cisdiamminedichloroplatinum(II) accumulation and sensitivity by forskolin and 3isobutyl-1-methylxanthine in sensitive and resistant human ovarian carcinoma cells. Int. J. Cancer. 48:866-872.

11. Mann, S. C., P. A. Andrews, and S. B. Howell. 1990. Short-term cisdiamminedichloroplatinum (II) accumulation in sensitive and resistant human ovarian carcinoma cells. Cancer Chemother. Pharmacol. 25:236-240.

12. Shionoya, S., Y. Lu, and K. J. Scanlon. 1986. Properties of amino acid transport systems in K562 cells sensitive and resistant to cis-diamminedichloroplatinum( II ). Cancer Res. 46:3445-3448.

13. Waud, W. R. 1987. Differential uptake of cis-diamminedichloroplatinum(II) by sensitive and resistant murine L1210 leukemia cells. Cancer Res. 47:6549-6555.

14. Ortiz, D. F., L. Kreppel, D. M. Speiser, G. Scheel, G. McDonald, and D. W. Ow. 1992. Heavy metal tolerance in the fission yeast requires an ATPbinding cassette-type vacuolar membrane transporter. EMBO (Eur. Mol. Biol. Org.) J. 11:3491-3499.

15. Conklin, D. S., J. A. McMaster, M. R. Culberston, and C. Kung. 1992. COT1, a gene involved in cobalt accumulation in Saccharomyces cerevisiae. Mol. Cell. Biol. 12:3678-3688.

16. Kamizono, A., M. Nishizawa, Y. Teranishi, K. Murata, and A. Kimura. 1989. Identification of a gene conferring resistance to zinc and cadmium ions in the yeast Saccharomyces cerevisiae. Mol. Cell. Genet. 219:161-167.

17. Nies, D. H. 1992. CzcR and CzcD, gene products affecting regulation of resistance to cobalt, zinc, and cadmium (czc system) in Alcaligenes eutrophus. J. Bacteriol. 174:8102-8110.

18. Nies, D. H. 1992. Resistance to cadmium, cobalt, zinc. and nickel in microbes. Plasmid. 27:17-28.

19. Callahan, H. L., and S. M. Beverley. 1992. Heavy metal resistance: a new role for $P$-glycoproteins in Leishmania. J. Biol. Chem. 266:18427-18430.

20. Wu, J., and B. P. Rosen. 1993. Metalloregulated expression of the ars operon. J. Biol. Chem. 268:52-58.
21. Kaur, P., and B. P. Rosen. 1992. Plasmid-encoded resistance to arsenic and antimony. Plasmid. 27:29-40.

22. Eastman, A. 1983. Characterization of the adducts produced in DNA by cis-diamminedichloroplatinum( II) and cis-dichloro-(ethylene-diamine)platinum(II). Biochemistry. 22:3927-3933.

23. Disaia, P. J., J. G. Sinkovics, F. N. Rutledge, and J. P. Smith. 1972. Cellmediated immunity to human malignant cells. Am. J. Obstet. Gynecol. 114:979989.

24. Behrens, B. C., T. C. Hamilton, H. Masuda, K. R. Grotzinger, J. WhangPeng, K. G. Louie, T. Knutzen, W. M. McKoy, R. C. Young, and R. F. Ozols. 1987. Characterization of a cis-diamminedichloroplatinum(II)-resistant human ovarian cancer cell line and its use in evaluation of platinum analogues. Cancer Res. 47:414-418.

25. Krause, C. J., T. E. Carey, R. W. Ott, C. Hurbis, K. D. McClatchey, and J. A. Regezi. 1981. Human squamous cell carcinoma: establishment and characterization of new permanent cells lines. Arch. Otolaryngol. 107:703-710.

26. Grenman, R., D. Burk, E. Virolaien, R. N. Buick, J. Church, D. R. Schwartz, and T. E. Carey. 1989. Clonogenic cell assay for anchorage-dependent squamous carcinoma cell lines using limiting dilution. Int. J. Cancer. 44:131136

27. Nakata, B., R. Barton, S. B. Howell, and G. Los. 1994. Association between over-expression of hsp60 and cisplatin resistance in head and neck cancer cells. Proc. Am. Assoc. Cancer Res. 35:466. (Abstr.)

28. Bradford, M. M. 1976. A rapid and sensitive method for the quantitation of microgram quantities of protein using the principle of protein-dye binding. Anal. Biochem. 72:248-254.

29. Rosen, B. P., and M. G. Borbolla. 1984. A plasmid-encoded arsenite pump produces arsenite resistance in Escherichia coli. Biochem. Biophys. Res. Commun. 124:760-765.

30. Christen, R. D., A. P. Jekunen, J. A. Jones, F. B. Thiebaut, D. R. Shalinsky, and S. B. Howell. 1993. In vitro modulation of cisplatin accumulation in human ovarian carcinoma cells by pharmacologic alteration of microtubules. J. Clin. Invest. 92:431-440.

31. Licht, T., H.-H. Fiebig, K. J. Bross, F. Herrmann, D. P. Berger, R. Shoemaker, and R. Mertelsmann. 1991. Induction of multiple-drug resistance during anti-neoplastic chemotherapy in vitro. Int. J. Cancer. 49:630-637.

32. Toffoli, G., A. Viel, L. Tumiotto, G. Biscontin, C. Rossi, and M. Boiocchi. 1991. Pleiotropic-resistant phenotype is a multifactorial phenomenon in human colon carcinoma cell lines. Br. J. Cancer. 63:51-56.

33. Hromas, R. A., J. A. North, and C. P. Burns. 1987. Decreased cisplatin uptake and binding as a mechanism of resistance in L1210 leukemia cells. Cancer Lett. 36:197-201.

34. Mann, S. C., P. A. Andrews, and S. B. Howell. 1988. Comparison of lipid content, surface membrane fluidity, and temperature dependence of cisdiamminedichloroplatinum(II) accumulation in sensitive and resistant human ovarian carcinoma cells. Anticancer Res. 8:1211-1216.

35. Broer, S., G. Ji, A. Broer, and S. Silver. 1993. Arsenic efflux governed by the arsenic resistance determinant of Staphylococcus aureus plasmid pI 258 . J. Bacteriol. 175:3480-3485.

36. Pison, R. L. 1991. Characterization of a phosphate transport system in human fibroblast lysosomes. J. Biol. Chem. 266:979-985.

37. Papadopoulou, B., S. Dey, G. Roy, K. Grondin, D. Dou, B. P. Rosen, and M. Ouellette. 1993. Oxyanion resistance and $P$-glycoprotein gene amplification in Leishmania. Gen. Motors Cancer Res. Found. Meeting, Toronto. (Abstr.)

38. Neal, R. A., J. van Bueren, N. G. McCoy, and M. Iwobi. 1989. Reversal of drug resistance in Trypansoma cruzi and Leishmania donovani by verapamil. Trans. R. Soc. Trop. Med. Hyg. 83:197-198.

39. Grogl, M., R. K. Martin. A. M. J. Oduola, W. K. Milhous, and D. E. Kyle. 1991. Characteristics of multidrug resistance in Plasmodium and Leishmania: detection of P-glycoprotein-like components. Am. J. Trop. Med. Hyg. 45:98-111. 